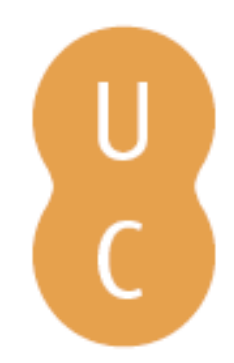

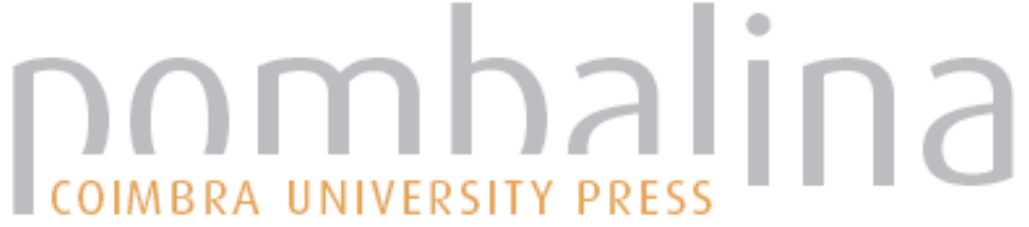

\section{Alimentação e suplementos}

\author{
Autor(es): $\quad$ Oliva, Mónica
}

Publicado por: Imprensa da Universidade de Coimbra

URL

persistente: $\quad$ URI:http://hdl.handle.net/10316.2/43111

DOI: $\quad$ DOI:https://doi.org/10.14195/978-989-26-1300-0_10

Accessed : $\quad$ 26-Apr-2023 13:31:13

A navegação consulta e descarregamento dos títulos inseridos nas Bibliotecas Digitais UC Digitalis, UC Pombalina e UC Impactum, pressupõem a aceitação plena e sem reservas dos Termos e Condições de Uso destas Bibliotecas Digitais, disponíveis em https://digitalis.uc.pt/pt-pt/termos.

Conforme exposto nos referidos Termos e Condições de Uso, o descarregamento de títulos de acesso restrito requer uma licença válida de autorização devendo o utilizador aceder ao(s) documento(s) a partir de um endereço de IP da instituição detentora da supramencionada licença.

Ao utilizador é apenas permitido o descarregamento para uso pessoal, pelo que o emprego do(s) título(s) descarregado(s) para outro fim, designadamente comercial, carece de autorização do respetivo autor ou editor da obra.

Na medida em que todas as obras da UC Digitalis se encontram protegidas pelo Código do Direito de Autor e Direitos Conexos e demais legislação aplicável, toda a cópia, parcial ou total, deste documento, nos casos em que é legalmente admitida, deverá conter ou fazer-se acompanhar por este aviso. 
Capítulo 10.

Alimentação e suplementos
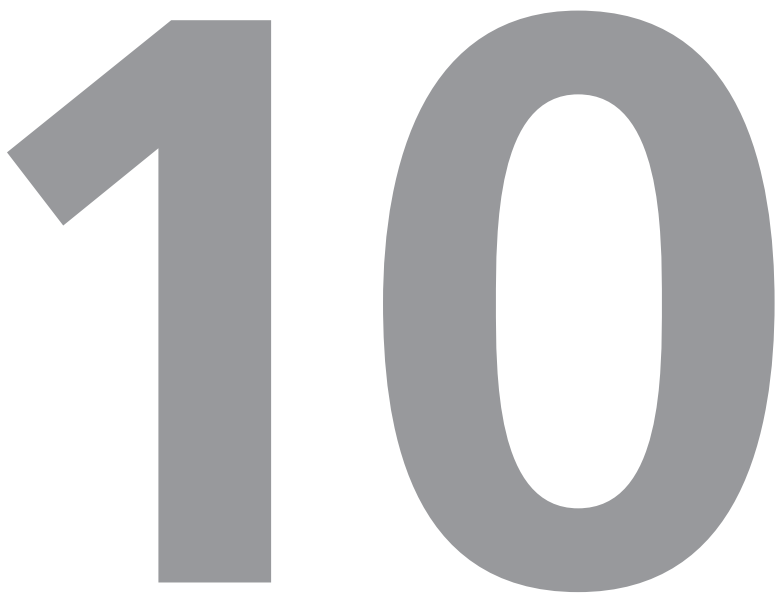

\section{Mónica Oliva}




\subsection{CONTEXTO}

A infância e principalmente o primeiro ano de vida, constituem uma oportunidade única para estabelecer hábitos nutricionais adequados, que garantam um crescimento apropriado mas também que estimulem a procura ao longo da vida de alimentos saudáveis, de modo a evitar mais tarde, o aparecimento de doenças relacionadas com a alimentação como a obesidade.

A designação lactente refere-se ao período desde o nascimento até aos 12 meses de vida, durante o qual a alimentação da criança é essencialmente baseada no leite.

\subsection{DESCRIÇÃO DO TEMA}

\subsubsection{Leite materno}

O leite materno é um alimento vivo, completo e natural, barato e seguro uma vez que respeita as limitações fisiológicas do tubo digestivo, do metabolismo e da função renal, dos primeiros meses de vida. O aleitamento materno tem vantagens para a mãe (involução uterina mais precoce, menor probabilidade de cancro da mama), para o lactente (menor risco de infeções gastrointestinais e respiratórias, dermatite atópica e asma, entre outros) e promove uma vinculação precoce ente a mãe e o filho.

\section{Fisiologia}

Ao longo da gravidez a mama, sob influência hormonal, diferencia-se de modo a ficar apta a produzir leite. Este processo ocorre em todas as mulheres independentemente do tamanho da mama.
A produção e a eliminação ou ejeção do leite dependem de um reflexo neuroendócrino (figura 1). Durante a sucção há estimulação de mecanorrecetores do mamilo e da aréola sendo enviados impulsos nervosos, que por meio do hipotálamo, levam à libertação na hipófise de duas hormonas: a prolactina e a ocitocina.

Por ação da prolactina, é produzido o leite materno ficando armazenado no lúmen alveolar. Existem fatores locais que inibem a produção de leite sempre que este se acumula na mama.

A ocitocina estimula a contração das células mioepiteliais que envolvem os alvéolos e os canais galactóforos, sendo o leite conduzido dos alvéolos aos canais e seios galactóforos - reflexo de ejeção. Só então o leite poderá ser retirado pela língua do bebé. O stresse pode bloquear este reflexo ficando o leite retido na mama, comprometendo a lactação.

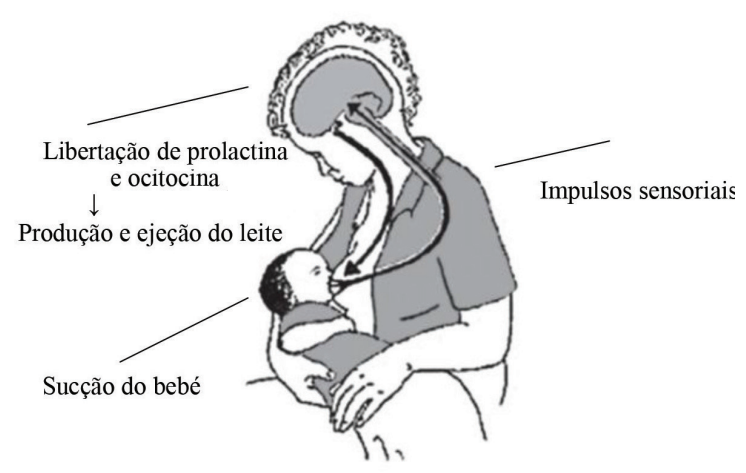

Figura 1. Reflexo neuroendócrino envolvido na produção de leite materno.Adaptado de Manual de aleitamento materno. Comité Português para a UNICEF/Comissão Nacional Iniciativa Hospitais Amigos dos Bebés 2012. 

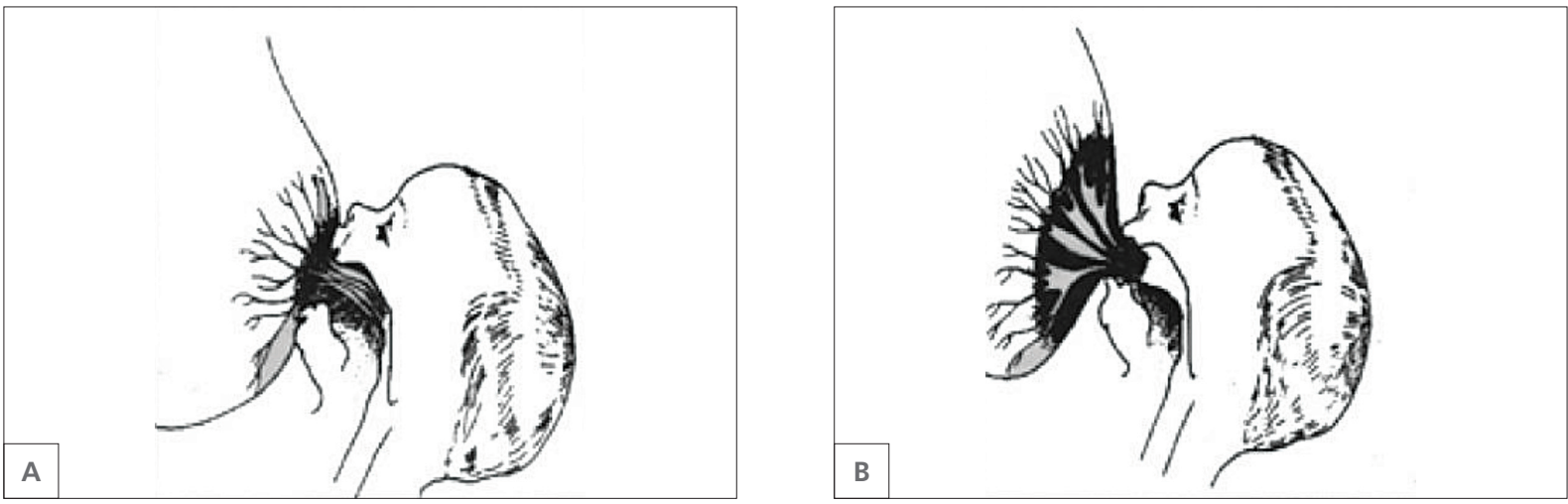

Figura 2. Técnica de amamentação.

A. Bebé bem posicionado, a boca apanha a maior parte da aréola e dos tecidos subjacentes, incluindo os seios galactóforos.

B. Bebé mal posicionado, a sucção é feita apenas no mamilo.

Adaptado de Manual de aleitamento materno.

Comité Português para a UNICEF/Comissão Nacional Iniciativa Hospitais Amigos dos Bebés 2012.

Tendo presente estas noções é fácil compreender que a introdução de qualquer suplemento, ao reduzir a estimulação e ao favorecer o não esvaziamento da mama, inibe a produção de leite. Este é um dos motivos pelos quais não está aconselhada a administração de outros líquidos como chá ou até água durante o aleitamento exclusivo. Quando um lactente mama o suficiente para satisfazer as suas necessidades calóricas, já está a receber água suficiente para responder também às suas necessidades hídricas, mesmo num ambiente quente e seco.

\section{Composição do leite}

A composição do leite materno vai sofrendo várias modificações ao longo de toda a lactação, adaptando-se às necessidades do bebé. Chamase colostro à secreção mamária dos primeiros quatro dias; é rico em sódio, cloro e proteínas com funções protetoras como imunoglobulinas e lactoferrina. É importante informar a mãe desta função preventiva de infeções, dado que ainda permanece entre muitas a noção de que este leite é fraco ou insuficiente para o recém-nascido. O leite maduro é rico em hidratos de carbono e lípidos, importantes para a saciedade do bebé.

\section{Técnica de amamentação}

O correto posicionamento a mamar é fundamental para o sucesso do aleitamento, garantindo uma extração eficaz de leite e evitando o aparecimento de problemas mamários como fissuras, ingurgitamento e mastite. A mãe deve dar de mamar num lugar calmo, confortavelmente sentada ou deitada. O bebé e a mãe devem ficar frente a frente e a boca alinhada com o mamilo. Tocando com o mamilo na parte média do lábio inferior o bebé abrirá bem a boca. Nessa altura a mãe deve introduzir dentro da boca o mamilo e grande parte da aréola (figura 2). A língua fará então movimentos ondulantes, espremendo a aréola e o mamilo contra o palato duro, removendo o leite acumulado nos seios galactóforos situados por baixo da aréola. Só assim a sucção será eficaz. 
Alguns recém-nascidos quando expostos a tetinas artificiais (i.e. tetina de biberão, chupeta, mamilos de silicone) ficam confusos e passam a ter dificuldade em mamar eficazmente ao peito comprometendo o sucesso do aleitamento. É por este motivo que a OMS e a UNICEF recomendam não usar chupeta ou outras tetinas artificiais até que o aleitamento materno esteja bem estabelecido.

\section{Duração e frequência}

A duração da mamada não é importante, pois a maior parte dos bebés mama $90 \%$ do que precisa em quatro minutos. Alguns prolongam as mamadas, por vezes até 30 minutos ou mais; o importante é perceber se o bebé está a obter o leite e não está a fazer da mama da mãe uma chupeta, pois isto pode macerar os mamilos, criar fissuras e levar a que a mãe desista de amamentar.

Inicialmente o recém-nascido deve mamar nas duas mamas para estimular a produção máxima de leite. Depois aconselha-se esvaziar completamente uma mama antes de passar para a outra, de modo a obter o último leite, rico em lípidos, necessário para saciar o bebé e permitir um bom aumento ponderal. Muitos ficarão satisfeitos com o leite de uma só mama. Nas refeições sucessivas, alternar a mama com que se inicia.

Não devem fixar-se intervalos entre mamadas, o bebé deve mamar sempre que quiser, isto é sempre que tiver fome - regime livre das mamadas. Em geral, os bebés com leite materno fazem mamadas mais frequentes do que os alimentados com leite de fórmula. Horários rígidos não são fisiológicos e podem comprometer o sucesso do aleitamento. Uma boa progressão ponderal garante que o bebé está a ser bem alimentado.
Podem existir fases em que o apetite do lactente exceda a quantidade de leite produzida. Estes surtos de crescimento são marcados por um a dois dias de choro, agitação e aumento do desejo de mamar. Frequentemente ocorrem entre as três e as quatro semanas, terceiro e sexto mês de vida, embora possa variar. Se a mãe aumentar a frequência e o tempo das mamadas, a produção de leite aumentará dentro de um ou dois dias.

\section{Extração e armazenamento}

Sempre que necessário, o leite materno pode ser retirado manualmente ou com bomba. Cada extração poderá demorar entre 10 a 15 minutos, e deve ser feita cada duas ou três horas durante o dia e pelo menos uma vez à noite. O leite pode ser armazenado em recipientes esterilizados e conservado no frigorífico durante três dias, no congelador cerca de três meses ou na arca congeladora durante seis meses. Antes de utilizar deve ser descongelado, aquecido em água morna sem ferver e agitar antes de administrar.

\section{Problemas maternos}

É comum surgirem pequenos problemas maternos que se não forem devidamente orientados poderão comprometer o aleitamento. O ingurgitamento mamário pós parto é uma situação normal embora possa causar desconforto moderado a grave, dificuldade em iniciar o fluxo de leite e em posicionar corretamente o bebé a mamar. Nesses casos, a extração manual ou por bomba de uma pequena quantidade de leite antes da mamada ajudará a ultrapassar a situação. Um método alternativo consiste na aplicação de compressas húmidas mornas e massagem, antes da mamada, para facilitar a saída do leite. A aplicação 
de compressas frias no intervalo das mamadas ajudará a diminuir a dor. A sua prevenção passa por dar de mamar em horário livre e posicionar corretamente o bebé a mamar.

A principal causa de hipogalactia (produção de leite insuficiente para o bebé) são erros no aleitamento: horário e duração das mamadas impróprios, a introdução de suplementos de leite ou o mau posicionamento do bebé. Para aumentar a produção de leite sugere-se aumentar a frequência das mamadas e esvaziar completamente as mamas.

No início da amamentação é normal haver algum grau de desconforto ou dor nos mamilos. Se esta situação se prolongar ou se surgirem fissuras no mamilo, é necessário verificar e corrigir erros de posicionamento do bebé, dado ser esta a sua principal causa.

A mastite puerperal ocorre em 1 a $3 \%$ das mulheres que amamentam. Trata-se de um processo inflamatório do tecido conjuntivo interlobular, que pode ou não evoluir para sobreinfeção bacteriana, geralmente causada por estirpes menos virulentas do Staphylococcus aureus, pelo que o antibiótico de escolha deve ser a flucloxacilina ou a associação amoxicilina com ácido clavulânico. É importante manter a extração de leite dessa mama, esvaziando-a completamente para evitar o aparecimento de complicações como abcesso.

São frequentes alterações do humor pósparto. Cerca de 50 a $80 \%$ das puérperas passarão por um período transitório de instabilidade emocional - disforia pós-parto ou blues. A depressão e a psicose embora mais raras devem ser precocemente identificadas e tratadas, pois comprometem a vinculação mãe-filho, a segurança, o crescimento e o desenvolvimento do recémnascido.

\section{Dieta materna}

Recomenda-se que a mãe faça uma alimentação saudável e variada.

Alguns sabores das comidas, condimentos e bebida ingeridos pela mãe passam para o líquido amniótico e para o leite materno. Esta exposição precoce veiculada pelo leite materno parece ser facilitadora da aceitação dos alimentos, mais tarde, aquando da diversificação alimentar.

O consumo de álcool está desaconselhado. Podem ser ingeridas até duas bebidas com cafeína por dia.

\section{Tabaco}

Para além da exposição ambiental, o filho de uma mãe fumadora recebe nicotina e os seus metabolitos através do leite materno. Esta exposição está associada ao aumento do risco do síndrome da morte súbita do lactente, de infeções respiratórias, para além de diminuir a produção de leite da mãe. Aconselha-se a suspender o seu consumo. Nos casos em que não seja possível, a mãe não deve fumar na presença do bebé e deve evitar fazê-lo nas duas horas e meia precedentes a uma mamada.

\section{Contraindicações}

A maioria das doenças infeciosas maternas não contraindica o aleitamento. O bebé, já esteve exposto durante o período prodrómico, e suspender o leite materno iria retirar-lhe os anticorpos e outras substâncias biológicas de que necessita. Contudo, em certas situações temporárias como quando a mãe tem varicela, herpes com 
lesões mamárias ou tuberculose ativa, não deve amamentar mas a produção de leite deve ser estimulada. $O$ aleitamento materno está contraindicado na infeção materna por vírus da imunodeficiência humana, na psicose materna ou nos recém-nascidos com doenças metabólicas como a galactosémia ou a fenilcetonúria.

A grande maioria dos fármacos é compatível com a amamentação mas evitar medicamentos desnecessários é a melhor regra a seguir.

São considerados contraindicações os citostáticos, os radiofármacos e as drogas de abuso.

\subsubsection{Leites ou fórmulas infantis}

Quando não é possível a amamentação, por ausência ou insuficiência de leite materno, quando este está contraindicado ou quando a mãe não quer amamentar, existem no mercado leites ou fórmulas infantis. Estes substitutos do leite humano são produtos elaborados a partir do leite de vaca, nutricionalmente seguros. Ao longo dos anos têm sido sucessivamente modificadas tendo como objetivo satisfazer as necessidades nutricionais e mimetizar o perfil de crescimento, de composição corporal, de marcadores bioquímicos e funcionais do lactente alimentado com leite materno. São exemplo de modificações introduzidas o enriquecimento em $\alpha$-lactalbumina bovina (permitindo uma redução do teor e uma melhoria da qualidade proteica), a hidrólise mais ou menos extensa das proteínas, a adição de nucleótidos, a adição de ácidos gordos polinsaturados de cadeia longa, de oligossacáridos e de bactérias probióticas.

Os leites ou fórmulas infantis são classificados de acordo com o grupo etário a que se destinam - leite para lactentes (leite 1) e leite de transição (leite 2).

Os leites 1 ou para lactentes estão indicados como suplemento ou substituto do leite materno nos primeiros seis meses de vida, podendo no entanto continuar a ser usados até aos 12 meses. Segundo uma revisão sobre leites e fórmulas infantis em Portugal, realizada em 2012 e publicada na revista da Sociedade Portuguesa de Pediatria, os leites 2 ou de transição apresentam uma densidade energética e proteica praticamente sobreponível à das fórmulas para lactentes mas um teor de cálcio, fósforo e ferro superior, estando apenas recomendados a partir do sexto mês e até aos 12-24 meses. Existem ainda leites especiais e fórmulas infantis com proteína de soja que poderão ser usados em situações clínicas bem definidas.

Mas, por mais evoluída que seja a tecnologia... o leite materno será sempre único.

Recomenda-se a preparação de fórmulas infantis no momento. Até aos quatro ou seis meses poderá ser usada água potável fervida ou engarrafada aquecida e o biberão e a tetina devem estar esterilizados. Por cada $\mathbf{3 0 ~} \mathbf{~ m l ~ d e ~}$ água adiciona-se uma colher medida rasa de pó, colocando-se em primeiro lugar o volume total de água. O cálculo de volume de leite a preparar para cada refeição tem em conta as necessidades diárias em água de um lactente $(150 \mathrm{ml} / \mathrm{Kg} / \mathrm{dia}$ até ao volume máximo $1000 \mathrm{ml} / \mathrm{dia}$ ), a dividir pelo número total de refeições diárias.

Quando o motivo para a introdução do leite adaptado foi a hipogalactia, o bebé deverá em todas as refeições, primeiro mamar nas duas mamas e só depois ser oferecido o biberão. Deste modo 
mantem-se a estimulação necessária à produção de leite materno.

\subsubsection{Diversificação alimentar}

O leite materno satisfaz todas as necessidades do lactente de termo, com peso de nascimento adequado, durante os primeiros quatro a seis meses de vida, devendo ser mantido pelo menos até ao final do primeiro ano de vida. A partir dos seis meses a quantidade de energia, proteínas, ferro, zinco e de algumas vitaminas deixa de ser suficiente pelo que é necessário introduzir outros alimentos. A duplicação do peso de nascimento, que habitualmente ocorre entre os quatro e os seis meses, é um bom indicador que as reservas em ferro se estão a esgotar e que é necessário introduzir outra fonte alimentar.

Entende-se por diversificação alimentar o fornecimento de qualquer alimento líquido ou sólido para além do leite, seja ele materno ou de fórmula, e tem como objetivos: variar as fontes de nutrientes além do leite, aumentar a oferta de ferro, manter uma ração calórica adequada ao peso da criança sem ter de aumentar excessivamente o volume dos alimentos administrados, fornecer fibras alimentares (úteis para a regularização do trânsito intestinal), preparar gradualmente a criança para a sua futura integração no regime alimentar da família. Embora não haja uma regra única para se efetuar a introdução de novos alimentos, existem alguns princípios orientadores que devem ser adaptados tendo em conta as características individuais do lactente (por exemplo quando existe alergia alimentar ou uma patologia especifica), a cultura e as condições socioeconómicas da família.
Uma correta diversificação pressupõe conhecer as diferentes necessidades nutricionais ao longo deste primeiro ano de vida, aguardar pela maturação do rim, do tubo digestivo (por volta do sexto mês) e do neurodesenvolvimento. Etapas como o controle dos movimentos da cabeça, a capacidade em ficar sentado (próximo do sexto mês), a perda do reflexo de extrusão da língua (a partir do quinto mês), o movimento de báscula, precursor da mastigação e o desenvolvimento da flexibilidade da língua (entre o sexto e o nono mês), condicionam a diversificação alimentar. Entre os oito e os 10 meses o lactente consegue "pinçar" com os dedos os alimentos previamente cortados, levá-los à boca, mastigá-los mesmo sem dentes e degluti-los. O adiar deste processo aumenta o risco de dificuldades alimentares no segundo ano de vida. Próximo dos 12 meses já deverá ter adquirido as competências necessárias para conseguir alimentar-se sozinho: é capaz de beber por um copo agarrando-o com as duas mãos e de pegar numa colher com alimentos e levá-la à boca.

A exposição precoce e variada a alimentos promove a aceitação de novos sabores. O gosto pelo doce e a aversão pelo amargo são inatos, a preferência para o salgado desenvolve-se a partir do segundo semestre de vida, mas a tolerância ao amargo ou o ácido dos legumes e da fruta, pode implicar oferecer mais de 10 vezes o mesmo alimento até ser aceite. Este treino de sabores constitui um ponto importante da diversificação uma vez que a janela para a habituação aos sabores começa a fechar-se pelos dois anos, habitualmente com tendência a manter-se uma alimentação monótona rica em calorias e pobre em outros nutrientes, com todos os riscos inerentes para a saúde futura. 
A administração de novos alimentos, sempre por colher, deverá ser feita de forma gradual, introduzindo um novo elemento cada três a cinco dias para se identificarem eventuais intolerâncias alimentares, oferecendo-o repetidamente até ser aceite, sem forçar. Desde sempre os pais devem aprender e respeitar sinais de saciedade da criança (fecha a boca, encosta-se para trás, vira a face indicando que não quer comer mais).

Todas estas etapas constituem períodos críticos de aprendizagem, que irão permitir a introdução de paladares e texturas diferentes e de alimentos cada vez mais sólidos, até à integração na alimentação da família que deverá acontecer por volta dos 12 meses.

Face ao exposto e de acordo com as recomendações da Sociedade Europeia de Gastroenterologia, Hepatologia e Nutrição e da Comissão de Nutrição da Sociedade Portuguesa de Pediatria, publicadas em 2012, a diversificação alimentar pode iniciar-se a partir do quarto mês, preferencialmente próximo dos seis meses e nunca depois desta data. Nos prematuros, para a introdução de novos alimentos deve ser tida em consideração a idade corrigida e não a cronológica.

Uma vez que é importante estimular o treino de sabores não doces, os autores defendem começar com um caldo ou puré de legumes embora possa ser com a farinha. A partir deste momento esta refeição substitui uma das refeições de leite embora nos primeiros dias, se necessário, ainda possa ser completada com o leite.

A batata, a cenoura, a abóbora, a cebola, o alho, o alho francês, a alface, a curgete, o brócolo e a couve branca, são os mais utilizados para se iniciar a diversificação. O espinafre, o nabo, a nabiça, a beterraba e o aipo contêm elevado teor de nitrato e fitato, razão pela qual só deverão ser introduzidos a partir dos nove a doze meses. Devem ser adicionados 5 a 7,5ml de azeite cru a cada dose de caldo ou puré de legumes uma vez que este alimento não contém gordura e os lípidos são necessários na estruturação das membranas celulares e na maturação do sistema nervoso central, retina e sistema imunológico.

Em alternativa o primeiro alimento a ser introduzido pode ser o cereal sob a forma de farinha, enriquecida em ferro. Existem no mercado farinhas lácteas (contém leite de fórmula pelo que devem ser reconstituídas com água) e não lácteas, para serem preparadas com leite materno ou com o leite que o lactente está a efetuar. Podem ainda ser isentas de glúten (se elaboradas a partir de milho ou arroz) ou com glúten (mistura de cereais). A introdução dos cereais com glúten está associada temporalmente à expressão clínica de doença celíaca em crianças com predisposição genética. O glúten poderá ser introduzido a partir dos quatro meses completos (17 semanas).

A carne, o peixe e o ovo fornecem proteínas de elevado valor biológico. A carne é também uma fonte importante de minerais de elevada biodisponibilidade como o zinco e o ferro e de ácidos gordos polinsaturados de cadeia longa, pelo que deve ser introduzida aos seis meses. O peixe poderá iniciar-se a partir do sétimo mês. Inicialmente com peixes mais magros como a pescada, o linguado, a solha e a faneca. O salmão, devido ao seu elevado teor em gordura, deverá ser introduzido depois dos 10 meses e em pequenas porções. Inicialmente a carne é administrada no caldo/puré de legumes, cerca de 20 a $30 \mathrm{~g}$ uma vez ao dia. A partir do sétimo mês não adicionar 
mais de $20 \mathrm{~g}$ de carne ou peixe por refeição em duas refeições por dia. A textura deve ser progressivamente menos homogénea para estimular a mastigação, aos nove meses podem passar a ser oferecidos com arroz branco ou massa e legumes cozidos.

A partir do nono mês, a gema do ovo poderá alternar com a carne ou o peixe, adiando-se a introdução da clara para depois dos 11 meses.

A fruta poderá ser introduzida por volta do quinto ou sexto mês, crua ou cozida, como complemento da refeição de caldo ou puré mas não deve constituir uma refeição. Maçã, pêra e banana são habitualmente os primeiros frutos a serem introduzidos. Devem ser oferecidos isoladamente para treinar o paladar e não sob a forma de sumo que tem várias desvantagens: efeito laxante, anorexiante, cariogénico e deseducador da paladar, pois habitua desde cedo a criança a bebidas doces. Durante o primeiro ano de vida dever-se-ão evitar frutos potencialmente alergogénicos ou libertadores de histamina como o morango, a amora, o kiwi e o maracujá. Pelo risco de asfixia também não devem ser dados alimentos redondos e duros como frutos secos, amendoins, pipocas, passas, tremoços, entre outros.

As leguminosas secas cozidas poderão ser introduzidas entre os nove e os onze meses, bem demolhados, inicialmente sem casca e em pequenas quantidades.

O leite de vaca em natureza tem um elevado teor de sódio, fósforo, gordura saturada e é pobre em ácidos gordos essenciais, ferro e vitaminas. Além disso, pode causar lesão da mucosa intestinal com hemorragia microscópica pelo que não deve ser introduzido como fonte láctea principal antes dos 12 meses. Contudo, o iogurte natural pode ser oferecido a partir dos nove meses em substituição da papa.

A água deverá ser a única bebida a ser administrada, várias vezes ao dia, desde o início da diversificação.

Não está recomendada a adição de sal, açúcar ou mel durante o primeiro ano de vida, pois para além dos efeitos negativos a curto prazo, treina a criança a procurar estes sabores ao longo da vida.

Para a confeção da refeição a família deve optar por alimentos de boa qualidade, isentos de contaminação por microrganismos patogénicos ou substâncias nocivas, manipulando-os de forma higiénica, servindo-os de imediato ou armazenando-os de forma segura.

Os "boiões" são alimentos infantis elaborados à base de frutos, legumes, carne ou peixe. Apesar de nutricionalmente adequados e sem risco de contaminação bacteriana, não devem substituir os alimentos preparados em família, reservando-se o seu uso para situações pontuais como uma viagem; respeitando sempre as indicações de utilização e conservação indicadas no rótulo.

As dietas restritivas como vegan ou macrobiótica apresentam um risco elevado de carências nutricionais (vitamina B12, folato, ferro, zinco, ácidos gordos e aminoácidos essenciais) pelo que estão desaconselhadas durante o primeiro ano de vida, período de rápido crescimento e desenvolvimento e por isso particularmente sensível a estes défices.

\subsubsection{Alimentação após \\ o primeiro ano de vida}

Facilmente percebemos pelo exposto a importância de um aconselhamento alimentar correto 
durante o primeiro ano de vida, promovendo a tolerância e o consumo de alimentos saudáveis, evitando carência de micronutrientes e excesso de macronutrientes, para que a criança saudável se torne num adulto, também ele saudável.

A recomendação de que ao ano de idade a criança passa a fazer a alimentação da família e em família, pressupõe que esta seja nutricionalmente adequada, o que frequentemente não se verifica. Alguns conselhos poderão ser:

- fazer a refeição em família, durante a qual a criança vê os outros elementos a comer os alimentos que the são oferecidos. Esta medida ajuda a diminuir a relutância em aceitar novos sabores, que se acentua a partir do primeiro ano (neofobias alimentares);

- respeitar desde sempre o apetite da criança. Em períodos de doença ou de crescimento mais lento o apetite será menor (é disso exemplo a anorexia fisiológica do segundo ano de vida que corresponde a uma fase de menor velocidade de crescimento global e por isso menor necessidade energética). Os pais devem preocupar-se com a qualidade dos alimentos oferecidos, garantindo uma oferta variada; a criança determina a quantidade a ingerir. Recorda-se a sábia frase do Pediatra Nicolau da Fonseca - " comida forçada é comida rejeitada";

- a refeição deve ser um momento de prazer, de convívio, pelo que a televisão deve estar desligada. Os ecrãs distraem a criança não permitindo que esta note os sinais de saciedade acabando por ingerir mais do que as suas necessidades. Além disso, o efeito da publicidade televisiva pode induzir a criança mais velha a ingerir alimentos nutricionalmente desequilibrados;

- evitar uma dieta monótona e nutricionalmente incompleta (aporte excessivo de proteína animal, açucares de absorção rápida e gordura saturada) e promover o consumo de vitaminas e fibra;

- não substituir alimentos ou refeições por leite, não dar leite antes de ir dormir e durante a noite. O aporte lácteo diário depois do primeiro ano não deve ultrapassar os $500 \mathrm{ml}$ por dia;

- não substituir refeições equilibradas por lanches ricos em hidratos de carbono como pão, bolachas ou doces.

Na adolescência são frequentes erros alimentares como: ausência do pequeno-almoço, ingestão regular de fast food, substituição de refeições por snacks hipercalóricos, excesso de consumo de carne em detrimento do peixe, redução do aporte de leite, fruta e legumes e aumento das bebidas açucaradas, por vezes com cafeína.

É pois necessário continuar a rever o regime alimentar nas consultas de vigilância de saúde infantil e juvenil não esquecendo que, mais importante do que o que se diz, é o que se faz ... e que a criança imitará o comportamento alimentar da família.

\subsubsection{Suplementos}

A vitamina D é um micronutriente, considerada por muitos como uma hormona, uma 
vez que pode ser sintetizada na pele através da exposição solar. A sua principal função é a regulação do metabolismo fosfo-cálcico, promovendo a absorção de cálcio para uma adequada mineralização óssea, evitando o raquitismo e a osteomalácia. Recentemente muitos estudos sugerem o envolvimento desta vitamina numa série de outras funções.

Tendo em conta que a exposição solar direta está desaconselhada durante o primeiro ano de vida e que poucos alimentos são naturalmente ricos nesta vitamina, recomenda-se desde os primeiros dias de vida, a suplementação oral com 400UI por dia de vitamina $\mathrm{D}$ durante o primeiro ano.

O Flúor é um mineral ubíquo, encontrado no solo, na água, nas plantas e animais e por isso um constituinte normal da alimentação. Tem um papel fundamental na prevenção e tratamento da cárie dentária da criança e do adulto. Esta ação é essencialmente tópica, após a erupção do dente, fortalecendo o esmalte e inibindo a atividade da placa bacteriana. Em Portugal, não está recomendada a suplementação sistémica com flúor mas sim a sua aplicação tópica logo após a erupção do primeiro dente. Os pais devem ser aconselhados a escovar os dentes duas vezes ao dia, uma das quais antes de deitar. Devem usar um dentífrico fluoretado com 1000-1500 ppm numa gaze, dedeira ou escova macia, de tamanho adequado à boca da criança. A quantidade de dentífrico depende da idade da criança, desde a erupção até aos seis anos deve ser igual ao tamanho da unha do quinto dedo da criança e a partir daí cerca de um centímetro.

O Ferro apesar de ser um oligoelemento ou seja constitui menos de $0,01 \%$ do peso corporal, é um importante componente de inúmeras proteínas incluindo enzimas e da hemoglobina. Ao contrário do ferro não hémico de origem vegetal, o ferro hémico da carne tem uma boa biodisponibilidade sendo por isso uma boa fonte alimentar deste mineral. A deficiência de ferro constitui a carência nutricional isolada mais frequente a nível mundial e a principal causa de anemia na infância. Vários estudos demonstraram uma associação entre anemia sideropénica, atraso de desenvolvimento psicomotor e alterações de comportamento a longo prazo. O elevado ritmo de crescimento e desenvolvimento cognitivo que ocorre nos primeiros três anos de vida, tornam as crianças desta faixa etária particularmente sensíveis a esta carência. São considerados fatores de risco para défice de ferro e anemia sideropénica: o baixo peso de nascimento, a clampagem precoce do cordão umbilical, o género masculino, o baixo consumo de alimentos ricos em ferro durante a diversificação alimentar, a ingestão excessiva de leite vaca e o baixo nível socioeconómico. De entre as medidas recomendadas para prevenir esta carência salienta-se a necessidade de suplementar com ferro (1 a 2mg/Kg/dia) os recém-nascidos com baixo peso de nascimento $(\leq 2.500 \mathrm{~g})$ durante os primeiros seis meses de vida. A partir dessa idade passa a ser fundamental a diversificação alimentar com um alimento rico em ferro como por exemplo a carne, não dar leite vaca durante o primeiro ano e restringir o seu consumo até máximo de $500 \mathrm{ml} / \mathrm{dia}$ até aos três anos. Os prematuros com peso de nascimento $\leq 1.800 \mathrm{~g}$ necessitarão de doses ligeiramente superiores ( 2 a $3 \mathrm{mg} / \mathrm{Kg} / \mathrm{dia}$ ) que poderão manter durante o primeiro ano de vida.

Exceto em situações clinicas particulares, não estão recomendados quaisquer outros suplementos, nomeadamente polivitamínicos, nem 
para o prematuro após as 40 semanas de idade corrigida, mas sim uma alimentação adequada.

\subsection{Factos a reter}

- Sempre que possível o aleitamento materno deverá manter-se em exclusivo até próximo dos seis meses e durante o primeiro ano de vida.

- Alguns lactentes poderão necessitar de alimentos complementares ao leite materno antes dos seis meses (mas não antes dos quatro) de modo a garantir um crescimento e neurodesenvolvimento normais.

- A diversificação alimentar deve ser fundamentada na evidência científica existente, mas respeitando as particularidades da criança e da família.

- A ordem de introdução dos outros alimentos, sempre por colher, deve ser flexível e escalonada; a complexidade e a textura das refeições devem progredir em paralelo com o desenvolvimento de competências alimentares.

- A exposição oral aos alimentos de forma regular e gradual favorece a sua tolerância.

- As dietas vegetarianas restritivas devem ser evitadas durante o primeiro ano vida.

- É fundamental promover alimentação saudável em todas as consultas de vigilância de saúde infantil e juvenil.

- Está recomentada a suplementação universal com vitamina $D$ durante o primeiro ano de vida, a suplementação com ferro ao lactente com baixo peso de nascimento e a aplicação tópica de dentífrico fluoretado desde a erupção do primeiro dente.
"Não comemos nutrientes, comemos alimentos e estes devem ser nutricionalmente adequados à idade da criança, mas também bem conservados, bem cozinhados, variados e apetecíveis e, logo que possível, consumidos em familia, pois a alimentação dos humanos é também um ritual de sociabilização, uma experiência de comunicação."

Gonçalo Cordeiro-Ferreira. Os principais erros alimentares. Guerra A (ed): Alimentação e Nutrição no Primeiros Anos de Vida. $7^{\circ}$ Workshop Nestlé Nutrition.

\subsection{EXEMPLOS PRÁTICOS}

1 - Calendário alimentar possível para diversificação aos quatro meses:

\begin{tabular}{|l|l|}
\hline Idade & $\begin{array}{l}\text { Tipo e número de } \\
\text { refeições, em média }\end{array}$ \\
\hline$<4$ meses & $\begin{array}{l}\text { Leite a pedido, de preferência } \\
\text { materno, 8 a 12 }\end{array}$ \\
\hline 4 meses & $\begin{array}{l}1 \text { de caldo de legumes ou 1 de farinha } \\
4 \text { a } 6 \text { de leite }\end{array}$ \\
\hline 5 meses & $\begin{array}{l}1 \text { de puré com carne }+ \text { fruta } \\
1 \text { de farinha } \\
3 \text { a } 5 \text { de leite }\end{array}$ \\
\hline 7 meses & $\begin{array}{l}2 \text { de puré com carne ou peixe }+ \text { fruta } \\
1 \text { de farinha } \\
2 \text { a } 4 \text { de leite }\end{array}$ \\
\hline 8 meses & $\begin{array}{l}\text { alimentos mais grumosos: carne/ } \\
\text { peixe, batata/massa/arroz cozidos } \\
\text { esmagados à parte com legumes }\end{array}$ \\
\hline$\geq 9$ meses & $\begin{array}{l}2 \text { de puré com carne ou peixe } \\
\text { ou gema de ovo + fruta } \\
1 \text { de farinha ou iogurte natural } \\
2 \text { a } 3 \text { de leite }\end{array}$ \\
\hline 12 meses & \begin{tabular}{l} 
integrar na alimentação da família \\
\hline
\end{tabular} \\
\hline
\end{tabular}


2 - Calculo regime alimentar para um lactente 3 meses, com peso de $6 \mathrm{Kg}$, sob leite fórmula para lactentes:

$1^{\circ}$ calcular as necessidades diárias em água $(150 \mathrm{ml} / \mathrm{kg} / \mathrm{dia}): 150 \mathrm{ml} \times 6 \mathrm{Kg}=900 \mathrm{ml}$

$2^{\circ}$ calcular o volume de água/refeição: $900 \mathrm{ml}$ $\div 8$ refeições $=112,5 \mathrm{ml}$.

$3^{\circ}$ num biberão esterilizado, colocar em primeiro lugar $120 \mathrm{ml}$ de água seguido de 4 colheres rasas de pó (1 colher por cada $30 \mathrm{ml}$ de água) de leite para lactentes.

$4^{\circ}$ verificar se está suplementado com $400 \mathrm{UI}$ de vitamina $\mathrm{D}$.

3 - Calculo regime alimentar para um lactente 8 meses, com $8,5 \mathrm{Kg}$ de peso, sob leite de fórmula:

$1^{\circ}$ calcular as necessidades diárias em água $(150 \mathrm{ml} / \mathrm{kg} / \mathrm{dia}): 150 \mathrm{ml} \times 8,5 \mathrm{Kg}=1.275 \mathrm{ml}$ (mas o volume máximo diário é $1000 \mathrm{ml}$ ).

$2^{\circ}$ calcular volume de água/refeição: $1000 \mathrm{ml}$ $\div 5$ refeições $=200 \mathrm{ml}$.

$3^{\circ}$ proposta para 5 refeições:

- 2 refeições de leite para lactentes ou de transição. Num biberão, colocar em primeiro lugar $210 \mathrm{ml}$ de água seguido de 7 colheres rasas de pó (1 colher por cada $30 \mathrm{ml}$ de água).

- 1 puré de legumes com carne e fruta.

- 1 farinha com glúten.

-1 puré de legumes com peixe e fruta. $4^{\circ}$ verificar se está suplementado com $400 \mathrm{UI}$ de vitamina $\mathrm{D}$.

\section{Leitura complementar}

Levy L, Bértolo H. Manual de aleitamento materno. Comité Português para a UNICEF/Comissão Nacional Iniciativa Hospitais Amigos dos Bebés 2012.

Guerra A, Rêgo C, Silva D, et al. Alimentação e nutrição do lactente. Acta Pediatr Port 2012:43(2):S17-S40.

Programa Nacional de Promoção da Saúde Oral. Circular Normativa n. ${ }^{\circ 1 / D S E}$ de 18/01/2005.

Braegger C, Campoy C, Colomb V, et al. Vitamin D in the Healthy European Paediatric Population. ESPGHAN Committee on Nutrition. J Pediatr Gastroenterol Nutr. 2013 Jun;56(6):692-701.

Domellöf M, Braegger C, Campoy C, et al. Iron Requirements of infants and Toddlers. ESPGHAN Committee on Nutrition. J Pediatr Gastroenterol Nutr. 2014 Jan;58(1):119-29.

Soares E, Pereira-da-Silva L, Cardoso M, Castro MJ. Vitaminas, Minerais e Oligoelementos por via Entérica no RecémNascido. Revisão do Consenso Nacional. Acta Pediatr Port 2015;46:159-69. 